\title{
Response of sugarcane ratoon to nitrogen without and with the application of silicon
}

\section{Bernardo Melo Montes Nogueira Borges, Thiago Batista Firmato De Almeida \& Renato De Mello Prado}

To cite this article: Bernardo Melo Montes Nogueira Borges, Thiago Batista Firmato De Almeida \& Renato De Mello Prado (2016) Response of sugarcane ratoon to nitrogen without and with the application of silicon, Journal of Plant Nutrition, 39:6, 793-803, DOI: 10.1080/01904167.2015.1109101

To link to this article: https://doi.org/10.1080/01904167.2015.1109101

Accepted author version posted online: 09

Nov 2015.

Published online: 31 May 2016.

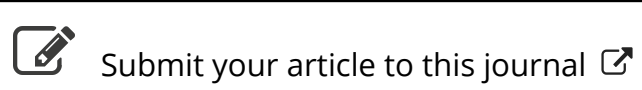

山ll Article views: 99

View Crossmark data ¿

Citing articles: 3 View citing articles $₫$ 


\title{
Response of sugarcane ratoon to nitrogen without and with the application of silicon
}

\author{
Bernardo Melo Montes Nogueira Borges, Thiago Batista Firmato De Almeida, \\ and Renato De Mello Prado
}

Department of Soil Science, Sao Paulo State University, Jaboticabal, Sao Paulo, Brazil

\begin{abstract}
The objective was to evaluate the effect of nitrogen, associated to silicon, on soil chemical properties, nutritional status and yield of the second sugarcane ratoon. The experiment was carried out at a Haplustox, loamy texture. The treatments consisted of urea rates of $0,40,80,120$ and $160 \mathrm{~kg} \mathrm{ha}^{-1}$ and two sources of correctives: silicate and lime. The use of nitrogen $(\mathrm{N})$ associated with silicate and lime did not affect soil fertility; however, the use of silicate increased soil silicon content at harvest. Growth variables were not affected by the application of the treatments, except stalk number at harvest, which increased in the presence of silicon. $\mathrm{N}$ rates and the correctives did not affect the crop nutritional status, but affected the $\mathrm{N}$ and Si accumulation in the plant. The $\mathrm{N}$ rates increased the sugarcane ratoon yield regardless the use of silicate; however, they did not affect its technological quality.
\end{abstract}

\section{ARTICLE HISTORY}

Received 4 July 2013

Accepted 20 May 2014

\section{KEYWORDS}

Saccharum spp; fertilization; lime; silicate; sugarcane ratoon

\section{Introduction}

The mechanical sugarcane harvesting leaves a great quantity of straw on the soil surface. As sugarcane is a semi-perennial plant and provides several harvests from the same ratoon, it is important to understand the benefits generated to the crop by the straw accumulated along the years; Holland and Coleman (1987) suggest that the carbon (C) retention is increased in conservationist cultivations, due to the trash decomposition by bacteria.

The soil coverage created by the straw raises water infiltration into the soil, decreases erosion and evaporation and increases the soil cation exchange capacity; additionally, it is a nutrient source, as there are reports that describe that part of the plant-absorbed nitrogen comes from the sugarcane trash mineralized nitrogen (N) (Gava et al., 2003).

In this new sugarcane production system, there is little information about the nitrogen dynamic in the soil-plant system referring to the sugarcane ratoon. According to Thornburn et al. (2002), the nitrogen rate in no burn sugarcane should be $60 \mathrm{~kg} \mathrm{ha}^{-1}$ higher than when using fire. Furthermore, there are even fewer studies in Brazil, which are restricted in Oxisols (Prado and Pancelli, 2008; Brito et al., 2009) and Nitosols (Basanta et al., 2003).

The importance of nitrogen for plant nutrition, growth and yield are well known. However, its excess may cause an accentuated vegetative development, which decreases plant resistance to lodging, causes self-shading, increases tissue succulence and raises plant susceptibility to insects and pathogens. The effects of nitrogen excess in plants can be avoided by the use of silicon, as this nutrient confers tissue hardness and improves plant architecture (Marschner, 1995). 
Considerable silicon sources in agriculture are the metallurgy slags that are basically constituted by calcium and magnesium silicates, which are correctives of the soil acidity and sources of calcium and magnesium.

The research hypothesis, therefore, was based on the fact that the sugarcane ratoon response to nitrogen application can be improved when it is associated with silicate.

The objective was to evaluate the effects of nitrogen application associated with silicate and lime on the soil chemical properties, nutritional status and crop yield of the second sugarcane ratoon.

\section{Materials and methods}

The experiment was carried out in the Jaboticabal (São Paulo State, Brazil) campus of the State University of São Paulo (UNESP), located at $21^{\circ} 15^{\prime \prime} 22^{\prime \prime} \mathrm{S}$ and $48^{\circ} 15^{\prime \prime} 18^{\prime \prime} \mathrm{W}, 610 \mathrm{~m}$ altitude. According to the Köppen classification, the climate is classified as megathermal dry in winter (Aw), in a Haplustox, loamy texture (EMBRAPA, 2006).

The experiment was performed at the second sugarcane ratoon (variety RB 855156). After the first ratoon harvest, the trash was sampled at five points of $1 \mathrm{~m}^{2}$ each on the soil surface, with the objective to determine the amount of trash left at the experimental area; thus, the trash dry matter was defined $\left(12 \mathrm{t} \mathrm{ha}^{-1}\right)$. Furthermore, a chemical soil analysis was performed at the $0.0-$ $0.2 \mathrm{~m}$ layer after the first ratoon harvest, where the silicate and lime were applied, resulting, respectively, in the following: $\mathrm{pH}$ calcium chloride $\left(\mathrm{CaCl}_{2}\right), 4.3$ and 4.3; organic matter, 1.86 and $1.86 \mathrm{~g} \mathrm{~kg}^{-1}$; phosphorus (P) (resin), 14.6 and $14.6 \mathrm{~g} \mathrm{~kg}^{-1}$; potassium $(\mathrm{K}), 0.8$ and $0.8 \mathrm{cmol}_{\mathrm{c}}$ $\mathrm{kg}^{-1}$; calcium (Ca), 11.9 and $11.9 \mathrm{cmol}_{\mathrm{c}} \mathrm{kg}^{-1}$; magnesium $(\mathrm{Mg}), 5.3$ and $4.0 \mathrm{cmol}_{\mathrm{c}} \mathrm{kg}^{-1}$; total acidity [hydrogen $(\mathrm{H})+$ aluminum $(\mathrm{Al})$ ], 47.9 and $49.2 \mathrm{cmol}_{\mathrm{c}} \mathrm{kg}^{-1}$; sum of bases (SB), 17.8 and $16.9 \mathrm{cmol}_{\mathrm{c}} \mathrm{kg}^{-1}$; cation exchange capacity (CEC), 66.2 and $65.3 \mathrm{cmol}_{\mathrm{c}} \mathrm{kg}^{-1}$; base saturation (BS), 27 and 26\% (van Raij et al., 2001); ammonium $\left(\mathrm{NH}_{4}^{+}\right), 15.2$ and $15.9 \mathrm{mg} \mathrm{kg}{ }^{-1}$; nitrate $\left(\mathrm{NO}_{3}^{-}\right)$, 13.7 and $13.9 \mathrm{mg} \mathrm{kg}^{-1}$ (Cantarella and Trivelin, 2001); and silicon (Si), 2.5 and2.3 $\mathrm{cmol}_{\mathrm{c}} \mathrm{kg}^{-1}$ (Korndörfer et al., 2004).

Rainfall during the second ratoon growth was $1600 \mathrm{~mm}$ (July/2010 and August/2010: $0.0 \mathrm{~mm}$; September/2010: $141.9 \mathrm{~mm}$; Autumn/2010: $69.4 \mathrm{~mm}$; November/2010: 100.1 mm; December/2010: 225.3 mm; January/2011: $260.1 \mathrm{~mm}$; February/2011: $208.2 \mathrm{~mm}$; March/2011: $496.9 \mathrm{~mm}$; April/2011: 92.3 $\mathrm{mm}$; and May/2011: $7.0 \mathrm{~mm}$ ).

The experimental design used was randomized blocks, in a $5 \times 2$ factorial scheme, with five nitrogen rates $\left(0 ; 40 ; 80 ; 120\right.$; and $160 \mathrm{~kg} \mathrm{ha}^{-1}$ of $\left.\mathrm{N}\right)$ and two corrective materials: $0.9 \mathrm{t} \mathrm{ha}^{-1}$ of silicate (Total Neutralizing Power TNP $=85 \%$; calcium oxide $(\mathrm{CaO})=34.9 \%$; magnesium oxide $(\mathrm{MgO})=9.9 \%$; and silicon $(\mathrm{Si})=10.5 \%)$ in the presence of silicon and $1.0 \mathrm{t} \mathrm{ha}^{-1}$ of lime $(\mathrm{TNP}=85.1 \%$; $\mathrm{CaO}=$ $36.4 \%$; and $\mathrm{MgO}=14.0 \%$ ) in the absence of silicon, with four replications.

The corrective material rates were established according to the São Paulo State recommendation for sugarcane crops in order to reach $60 \%$ of BS (Spironello et al., 1997). However, only half of the calculated amount was used due to the superficial application without incorporation (Rossetto et al., 2004).

Plant sugarcane (crop 2008-2009) received different $\mathrm{N}$ rates due to its lower demand: 0, 30, 60, 90 and $120 \mathrm{~kg} \mathrm{ha}^{-1}$ of $\mathrm{N}$ (urea). This was also the case for the corrective materials: $2.19 \mathrm{t} \mathrm{ha}^{-1}$ of lime $(\mathrm{TNP}=86.2 \%$; calcium oxide $(\mathrm{CaO})=41.4 \%$; and magnesium oxide $(\mathrm{MgO})=10.6 \%)$ and $2.61 \mathrm{tha}^{-1}$ of silicate $(\mathrm{TNP}=72.3 \% ; \mathrm{CaO}=42.1 \% ; \mathrm{MgO}=12.4 \%$; and total silicon $(\mathrm{Si})=15 \%)$ were applied with the objective of raising the base saturation (BS\%) to $60 \%$.

The potassium was evenly applied on the plots, as potassium chloride, at the rate of $150 \mathrm{~kg} \mathrm{ha}^{-1}$ potassium oxide $\left(\mathrm{K}_{2} \mathrm{O}\right)$, according to the recommendation by Spironello et al. (1997).

Each experimental plot was composed of four plant rows of $6 \mathrm{~m}$ length, spaced $1.5 \mathrm{~m}$ from each other, resulting in a total area of $36 \mathrm{~m}^{2}$. For the evaluations, only the central rows were considered, resulting in an area of $18 \mathrm{~m}^{2}$. The plots were separated from each other by $1.5 \mathrm{~m}$ corridors.

For the growth evaluations, the number of stalks was considered along $1.5 \mathrm{~m}$, after four and nine months of sugarcane sprouting, as well as their height, diameter and yield at the harvest. 
The sampling for the evaluation of the sugarcane technological quality was also performed at the harvest time, which consisted of 10 stalks collected from the central row of each plot. For the technological quality analysis, the reducing sugars (RS\% Juice), reducing sugars (RS\% Cane), estimated sugar production (ESP), concentration of soluble solids (Brix\% Juice), sucrose (Pol\% Juice), Fiber\% Cane and Purity\% Juice were determined using the methods described by CONSECANA (2006).

Soil sampling was carried out every six months throughout the experimental period, between the sugarcane rows, at $0.1 \mathrm{~m}$ from the plants in the layers of $0.0-0.1,0.1-0.2,0.2-0.4$, and $0.4-0.6 \mathrm{~m}$ depth. The analytical determinations followed the methods described by van Raij et al. (2001), while the silicon determination followed the method described by Korndörfer et al. (2004).

For both years, part of the samples were conditioned in a cooler with ice and sent to the laboratory for the determination of ammonium $\left(\mathrm{NH}_{4}{ }^{+}\right)$and nitrate $\left(\mathrm{NO}_{3}{ }^{-}\right)$(Cantarella and Trivelin, 2001).

The nutritional status of the plants (macro- and micronutrients; Bataglia et al., 1983) was determined from the TVD (Top Visible Dewlap) leaf, using its central $0.2 \mathrm{~m}$ region and excluding the midrib, during the most vigorous vegetative growth stage after 9 months of sprouting.

Furthermore, samples from the aerial parts (stalk + leaves) were collected and dried in a forced-air circulation oven at $65^{\circ} \mathrm{C}$ until constant weight. From the dried matter, nitrogen and silicon content and their accumulation in the dry tissue was determined according to the methodology proposed by Bataglia et al. (1983) for nitrogen and by Kraska and Breitenbeck (2010) for silicon.

A variance analysis was performed on the resulting data. When the fluoride $(\mathrm{F})$ value was significant (Pimentel-Gomes and Garcia, 2002), the polynomial regression analysis was also carried out. For the soil variables, the statistical analysis was performed in split plots, so that the primary treatments were arranged in a $5 \times 2$ factorial scheme (five $\mathrm{N}$ rates in the presence or absence of silicon) and the secondary ones consisted of soil layers.

\section{Results and discussion}

\section{Treatment effects on the soil}

The soil chemical properties were not affected by the primary treatments ( $\mathrm{N}$ rates and corrective materials) at six and 12 months after ratoon sprouting, except by the silicon content in the soil after 12 months of sprouting (Tables 1 and 2). The silicate, when compared to lime, promoted higher silicon content in the soil regardless of the $\mathrm{N}$ rates (Table 2). This increment in soil silicon content due to the application of silicate occurs because of the presence of the element in its composition, which was also related by Pereira et al. (2010).

The nitrogen rates did not affect mineral $\mathrm{N}$ content in the soil, which was also observed by Primavesi et al. (2005) for forage plants. This may have resulted from soil nitrogen losses through leaching.

The soil chemical properties were affected by soil depth in samples collected at six and 12 months after ratoon sprouting, except for the $\mathrm{NH}_{4}{ }^{+}$and $\mathrm{NO}_{3}{ }^{-}$concentrations (Tables 1 and 2). Soil fertility in the superficial layer (0.0-0.1 $\mathrm{m}$ depth) was higher in the two samplings, as there were higher values of $\mathrm{pH}$, organic matter, $\mathrm{P}, \mathrm{K}, \mathrm{Ca}$ and $\mathrm{Mg}$, that reflected on the sum of bases (SB) and on the soil base saturation (BS) (Tables 1 and 2).

It was also noted that the $\mathrm{NH}_{4}{ }^{+}$and $\mathrm{NO}_{3}{ }^{-}$contents were similar in the layers of $0.0-0.6 \mathrm{~m}$ after six and 12 months of ratoon sprouting (Tables 1 and 2). These results indicate that the mineral nitrogen may have leached to deeper layers, unlike that which was reported by Donagemma et al. (2008), indicating that the ammonium moves with a greater facility to soil layers up to a depth of $0.6 \mathrm{~m}$.

The silicon content was higher in the deeper layers (0.4-0.6 m depth) at six and 12 months after sprouting (Tables 1 and 2). This may be explained due to leaching from the superficial layers (Fonseca, 2011) as there are indications that silicon is a mobile trace element in the soil, once it is found as a monosilicic acid that is susceptible to leaching (van Raij, 2011). 


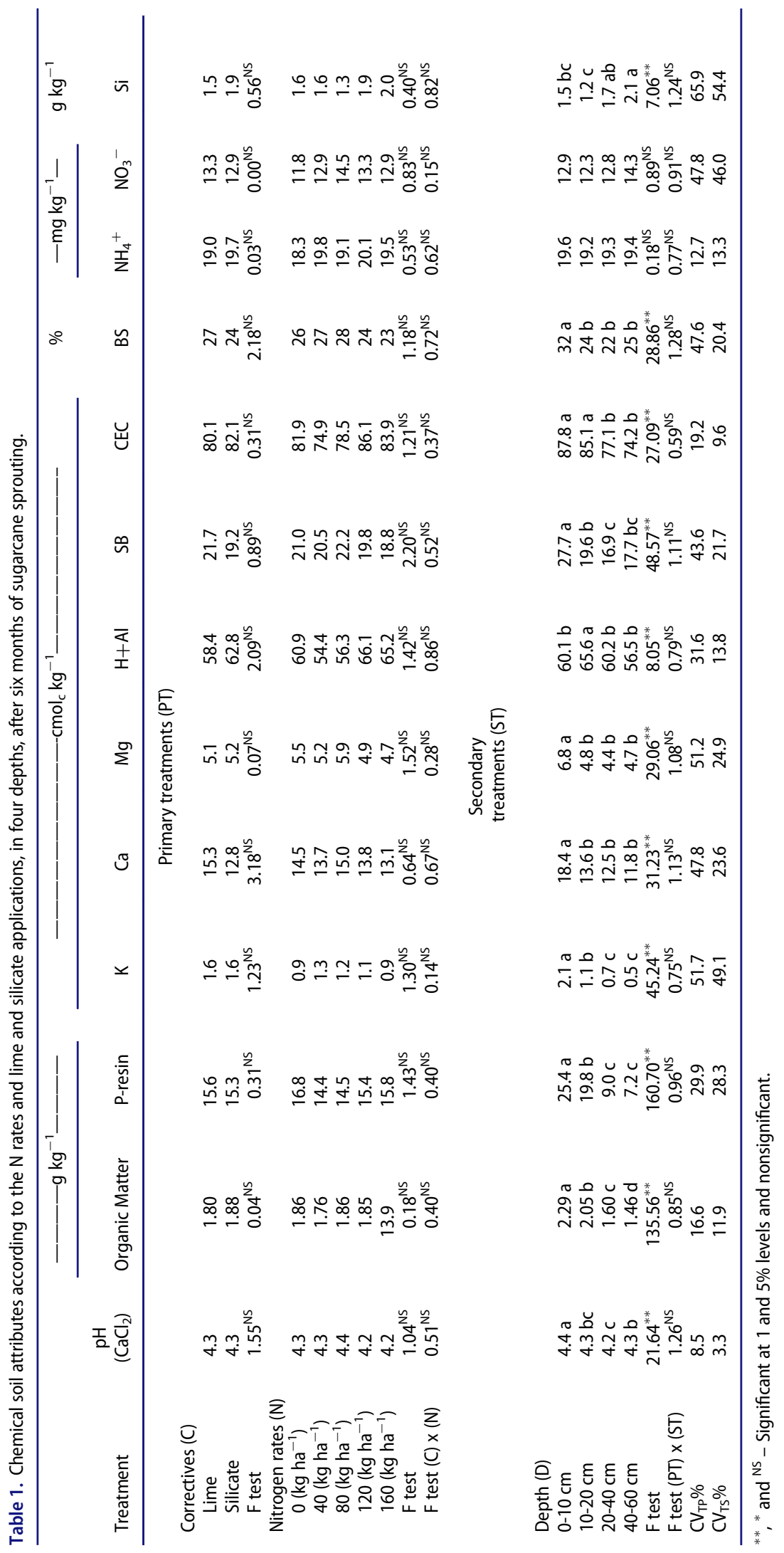




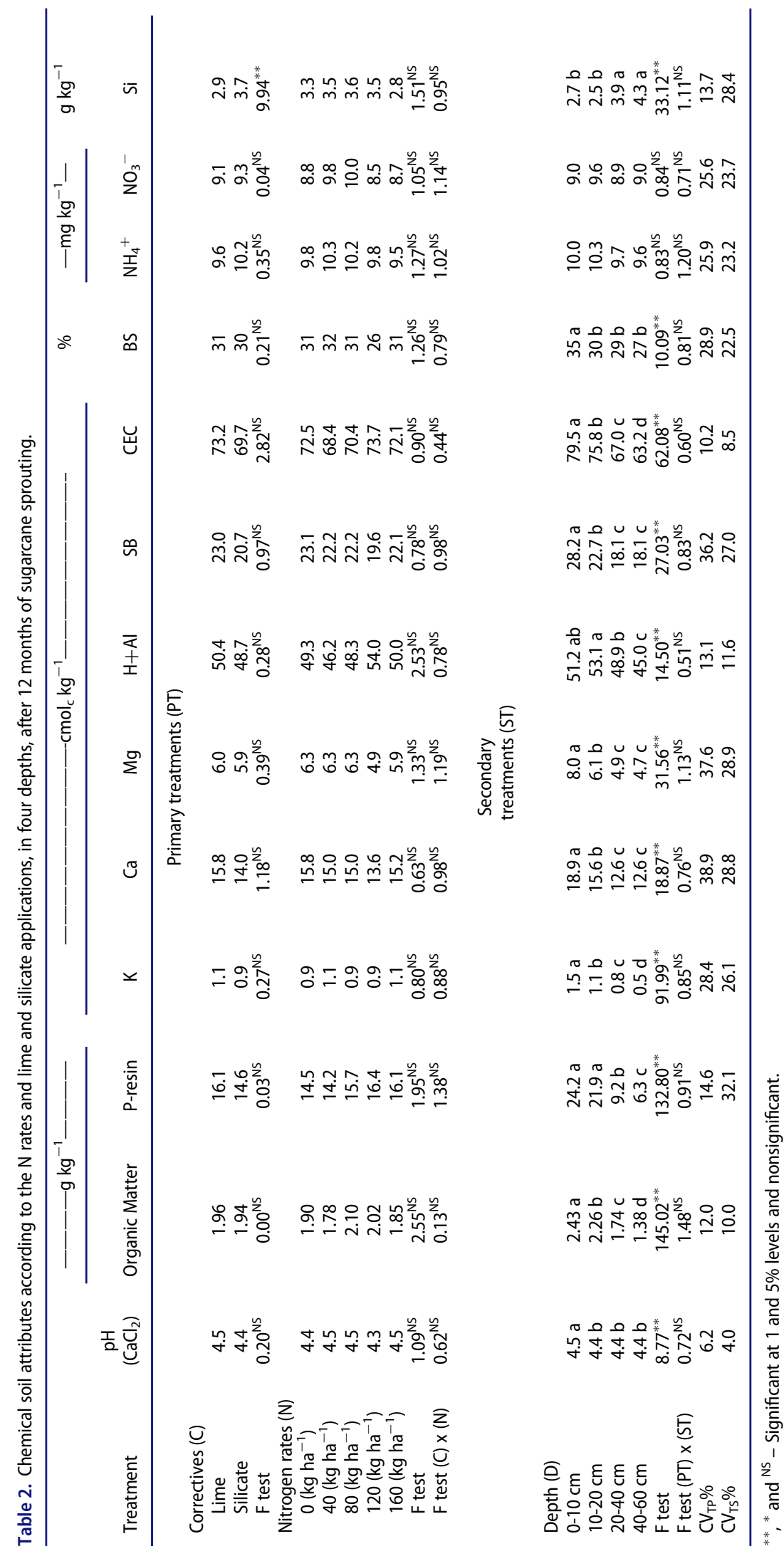




\section{Treatment effects on nutrition and accumulation}

The nitrogen rates implemented for the sugarcane ratoon significantly affected the $\mathrm{N}$, sulfur $(\mathrm{S}), \mathrm{Cu}$, and iron (Fe) leaf contents (Figure 1). The absence of the interaction shows that the nitrogen effects on the ratoon nutritional status are not influenced by the supply of Si to the plants.

The macro- and micronutrient contents in the TVD leaf did not differ regardless of the application of silicate, indicating that the silicate effects would be similar to the lime ones, concerning the availability of these nutrients to the plants (Fonseca et al., 2011). The $\mathrm{N}$ rates linearly increased with the increase of the $\mathrm{N}$ and $\mathrm{Si}$ contents, despite the application of the correctives (Figure 1a, b).

The nitrogen rates resulted in an appropriate $\mathrm{N}$ leaf content for Brazilian conditions (18 and $25 \mathrm{~g}$ $\mathrm{kg}^{-1}$ ) (van Raij and Cantarella, 1997), except for the control treatment $\left(17 \mathrm{~g} \mathrm{~kg}^{-1}\right)$, which was below that range. The other nutrient contents were considered appropriate, except for $S$ ( 0.9 to $1.3 \mathrm{~g} \mathrm{~kg}^{-1}$ ), which was below the adequate range $\left(1.5\right.$ to $\left.3.0 \mathrm{~g} \mathrm{~kg}^{-1}\right)$, as indicated by those same authors.

The nitrogen rates affected the $\mathrm{N}$ accumulation in leaves and stalks, while the correctives affected only the Si accumulation in leaves and stalks. There was an interaction among the $\mathrm{N}$ rates and corrective materials for the $\mathrm{N}$ and $\mathrm{Si}$ accumulation in leaves and $\mathrm{Si}$ accumulation in sugarcane stalks.

The $\mathrm{N}$ application associated with lime and silicate promoted a quadratic adjustment for the $\mathrm{N}$ accumulation in leaves, reaching its maximum value at the $\mathrm{N}$ rates of 47.5 and $65.4 \mathrm{~kg} \mathrm{ha}{ }^{-1}$, respectively. The $\mathrm{N}$ rate that provided a greater accumulation in leaves occurred in the presence of silicon $\left(\mathrm{N}=174 \mathrm{~kg} \mathrm{ha}^{-1}\right)$ when compared with lime $\left(\mathrm{N}=153 \mathrm{~kg} \mathrm{ha}^{-1}\right)$ (Figure 2a). This increase in the $\mathrm{N}$ absorption in the presence of $\mathrm{Si}$ also occurred in other crops, such as forages
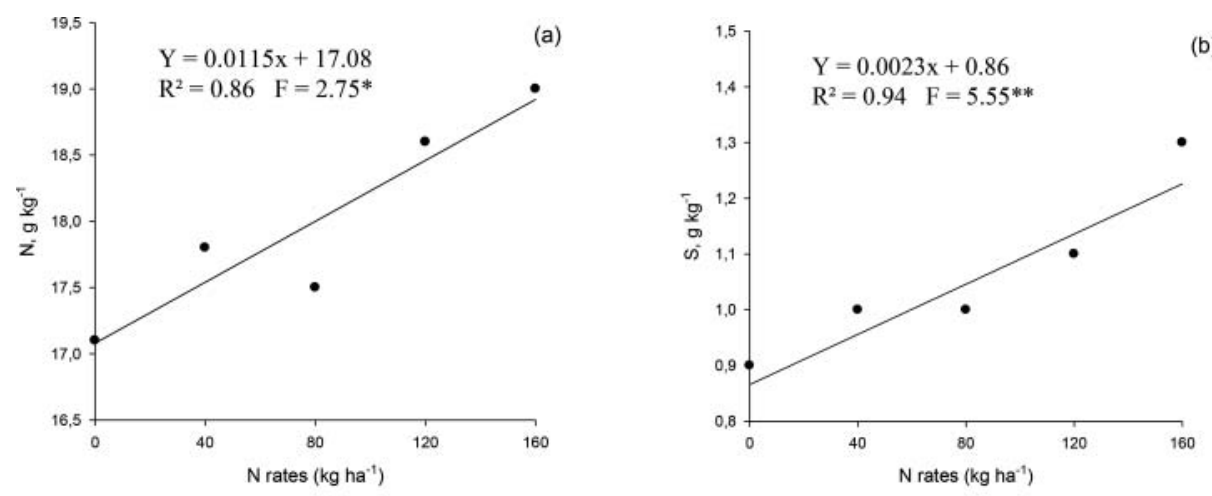

(b)
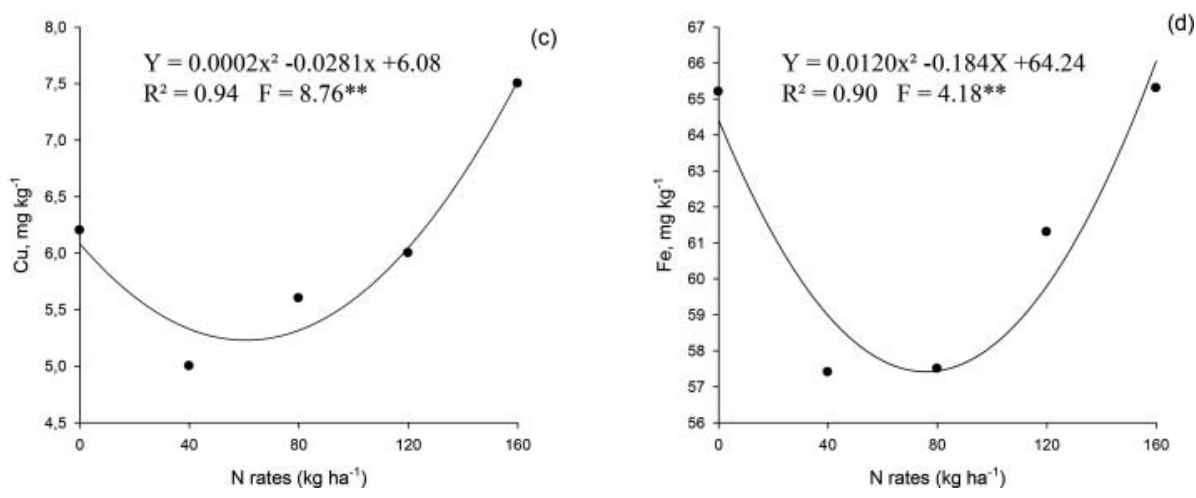

Figure 1. Effects of the $\mathrm{N}$ rates on the TVD leaf content of A) N, B) S, C) Cu, and D) Fe of sugarcane ratoons. ${ }^{* *},{ }^{*}$ and ${ }^{\mathrm{NS}}-\mathrm{Significant}$ at 1 and $5 \%$ levels and nonsignificant, according to the $F$ test. 

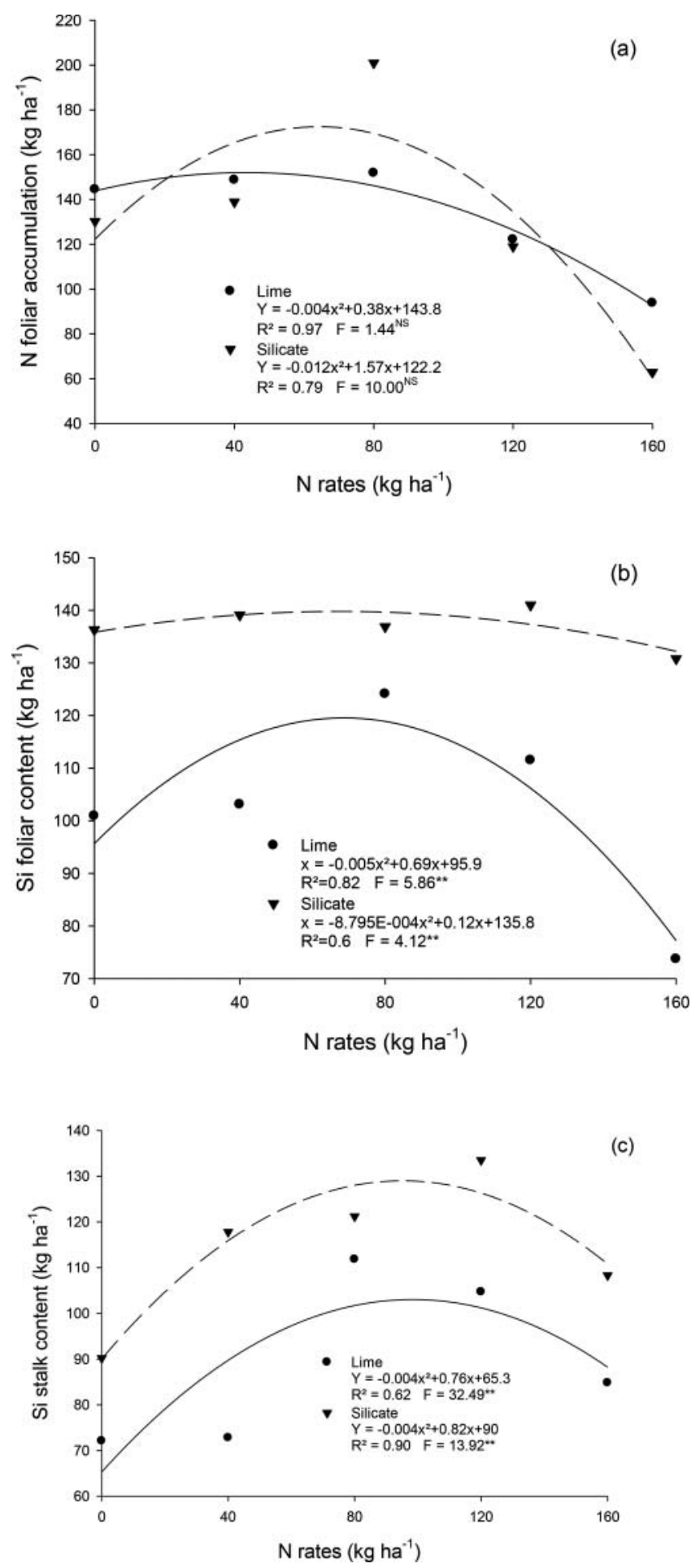

Figure 2. Nitrogen accumulation in A) leaves, B) silicon in leaves and C) stalks of sugarcane ratoons. ${ }^{* *},{ }^{*}$ and ${ }^{\text {NS }}-$ Significant at 1 and $5 \%$ levels and nonsignificant, according to the $\mathrm{F}$ test.

(Fonseca et al., 2011). We also observed that the nitrogen application with corrective materials lime and silicate, promoted a quadratic adjustment for Si accumulation, reaching its maximum value at the $\mathrm{N}$ rates of 69 and $66 \mathrm{~kg} \mathrm{ha}^{-1}$, respectively (Figure $2 \mathrm{~b}$ ). 
The Si accumulation in the stalks increased, with a quadratic adjustment, with the lime and silicate application, reaching its maximum value at the $\mathrm{N}$ rates of 95 and $103 \mathrm{~kg} \mathrm{ha}^{-1}$, respectively (Figure 2c). It was verified that the highest silicon accumulation in the sugarcane aerial parts (leaves + stalks) occurred in the presence of silicate $\left(261 \mathrm{~kg} \mathrm{ha}^{-1}\right)$ when compared with lime $\left(198 \mathrm{~kg} \mathrm{ha}^{-1}\right)$. In grasses, the silicon absorption also promoted an increase in macronutrient absorption, especially $\mathrm{N}$ (Fonseca et al., 2011).

\section{Treatment effects on stalk development and yield}

There were no significant differences among the treatments ( $\mathrm{N}$ rates and correctives) and their interactions for the height, number and diameter of tillers from the second sugarcane ratoon after four months of sprouting. After nine months of sprouting, the treatments affected only the number of stalks, with a highlighted response to the use of silicate.

At the last development evaluation of the sugarcane ratoon, plant height was affected by the nitrogen rates while stalk diameter was affected by the correctives. There was an interaction among the
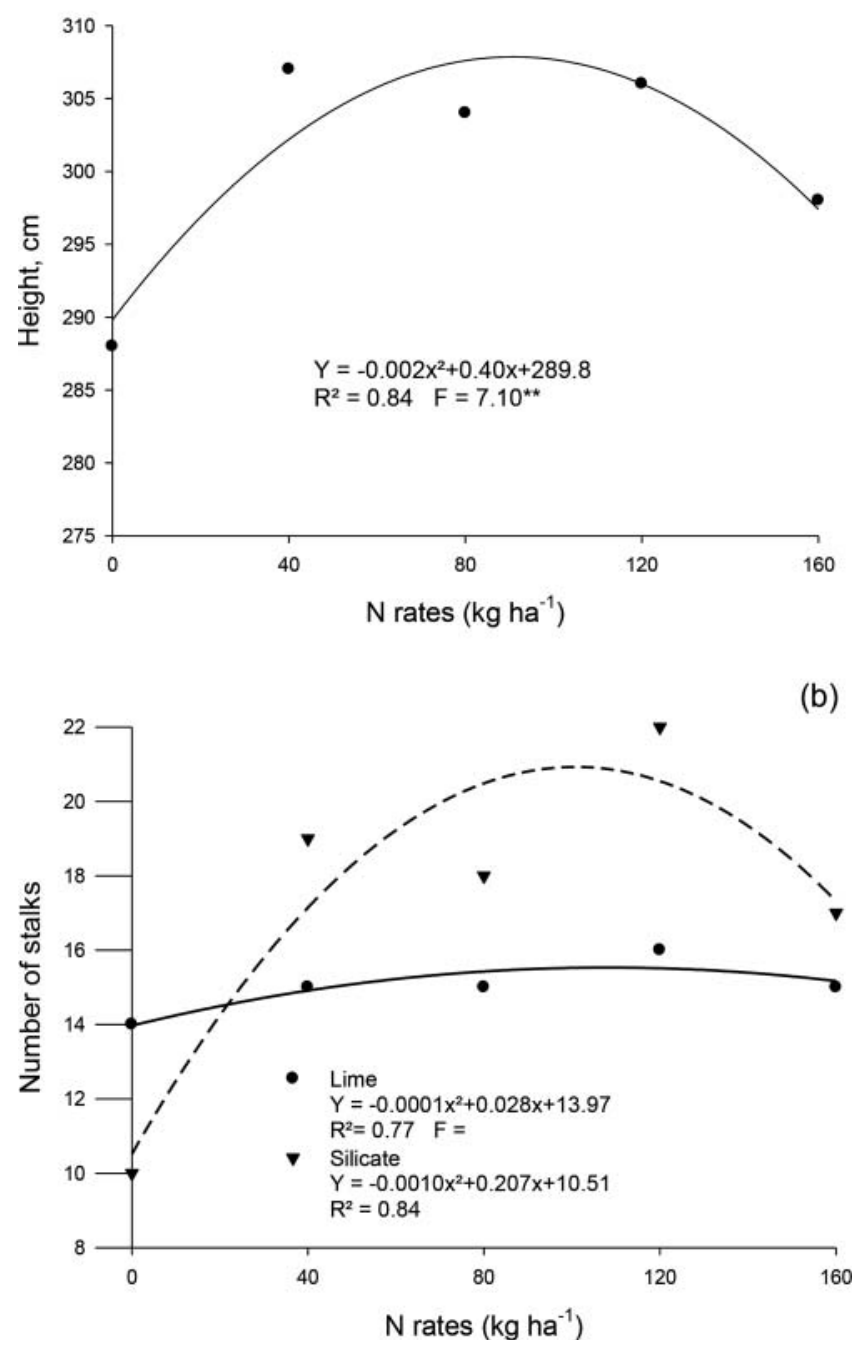

Figure 3. A) Stalk number and B) plant height after 12 months of sugarcane ratoon sprouting. ${ }^{* *},{ }^{*}$ and ${ }^{\text {NS }}-$ Significant at 1 and $5 \%$ levels and nonsignificant, according to the $\mathrm{F}$ test. 
nitrogen rates and correctives for stalk number. The nitrogen application promoted an increase with a quadratic adjustment for plant height, reaching its maximum value at $100 \mathrm{~kg} \mathrm{ha}^{-1} \mathrm{~N}$ (Figure $3 \mathrm{a}$ ). The nitrogen rates increased the stalk number, with a quadratic adjustment, reaching the maximum of 21 and 15 stalks at 103.5 and $140 \mathrm{~kg} \mathrm{ha}^{-1} \mathrm{~N}$, with the application of silicate and lime, respectively (Figure 3b).

There was a significant effect of the $\mathrm{N}$ rates and of the interaction among the $\mathrm{N}$ rates and correctives - lime and silicate, for the dry matter of leaves and stalks, which promoted a quadratic increase on leaf dry matter, reaching its maximum value at 95 and $102.5 \mathrm{~kg} \mathrm{ha}^{-1} \mathrm{~N}$ (Figure 4a). This fact indicates that the presence of silicon, when there is either a lack or excess of nitrogen, which acts as a beneficial element, reducing the detrimental effects on sugarcane growth and yield (Basto et al., 2010).

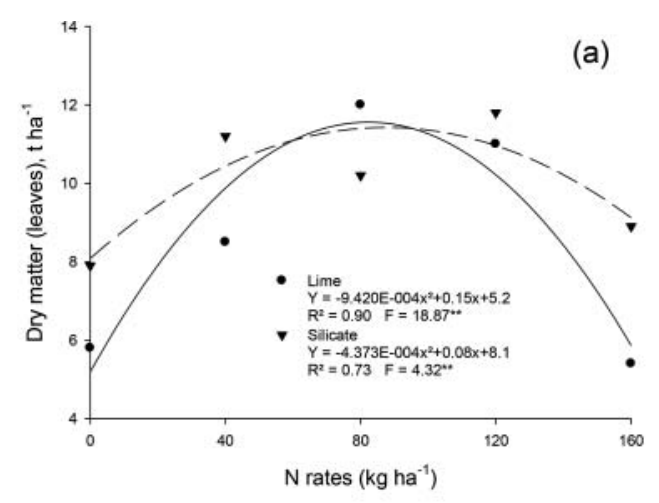

(b)
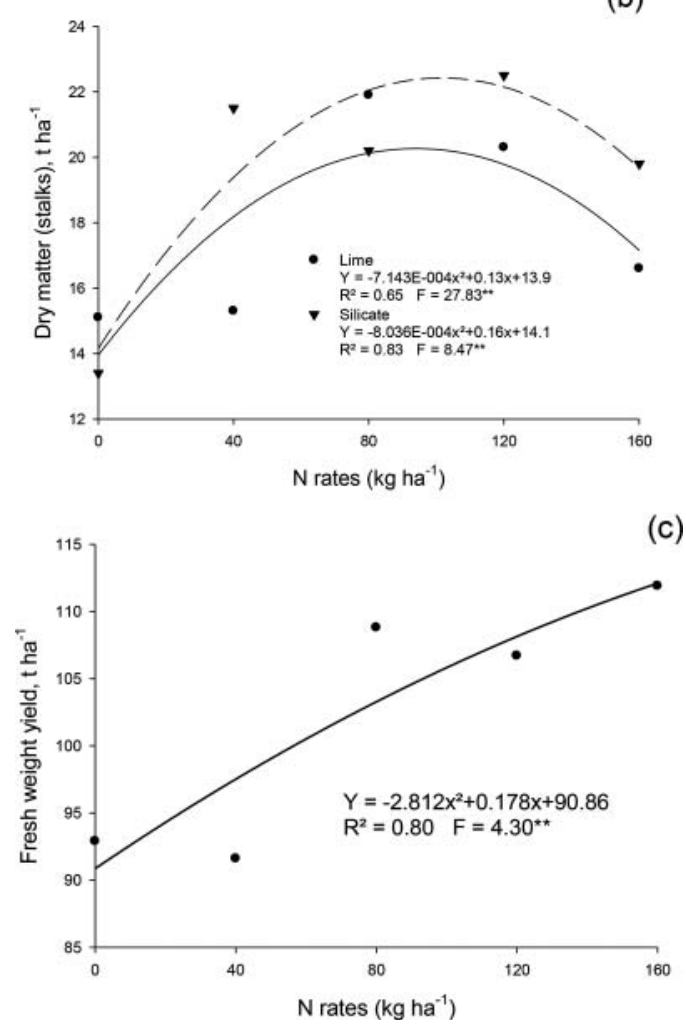

Figure 4. Dry matter of A) leaves and B) stalks and C) yield of sugarcane ratoons. ${ }^{* *},{ }^{*}$ and ${ }^{\text {NS }}$ - Significant at 1 and $5 \%$ levels and nonsignificant, according to the $\mathrm{F}$ test. 
The stalk yield increased up to $160 \mathrm{~kg} \mathrm{ha}^{-1} \mathrm{~N}$, despite the application of lime or silicate (Figure 4c), as the increase of the nitrogen rates promoted an increase in plant height, stalk number (Figure 3) and dry matter of leaves and stalks (Figure $4 \mathrm{a}$ and b). This shows that the silicon did not enhance stalk yield due to the nitrogen fertilization (Taiz and Zeiger, 2009), unlike that which was reported by Anderson et al. (1987) and Anderson (1991), where the silicate application increased sugarcane yield. These results agree with other authors who indicated an increase in the sugarcane ratoon yield, which was mechanically harvested, due to the nitrogen application (Shekinah et al., 2012).

\section{Treatment effects on the technological quality}

It was observed that the $\mathrm{N}$ rates and correctives and their interactions did not significantly affect the sugarcane technological quality, as observed by Shekinah et al. (2012) from the first sugarcane ratoon.

The technological quality results obtained for the second sugarcane ratoon from the treatments $-\mathrm{N}$ rates and correctives, showed a small variation: RS\% Juice (0.57 to 0.62), RS\% Cane (0.49 to 0.53), ESP (19.98 to $20.81 \%$ ), Brix\% Juice (20.71 to 21.51 ), Pol\% Juice (15.74 to 16.39), Fiber\% Cane (10.94 to 11.84 ) and Purity\% juice (87.99 to 89.29). These results are, therefore, considered appropriate, according to Ripoli and Ripoli (2004) (Pol\% Juice $>14$, Purity\% Juice $>85$, ESP $>15 \%$, RS $<0.8 \%$ and Fiber\% Cane between 11 and 13).

It was also noticed that the silicon use did not affect the sugarcane technological quality, which partly disagrees with Leite et al. (2008), who verified an increase in the stalk fiber content, and with Matichenkov and Calvert (2002), who indicated an increase in the sugar content of the plants.

\section{Conclusions}

The use of nitrogen associated with the use of silicate and lime did not affect the soil fertility; however, the use of silicate increased the soil silicon content after 12 months of sugarcane sprouting. The growth variables were not affected by the application of the treatments, except for the number of culms during the harvesting period, which were increased by the silicon presence. The $\mathrm{N}$ rates and correctives did not affect the crop nutritional status, but they did affect the $\mathrm{N}$ and Si accumulation in the plant. The $\mathrm{N}$ rates increased the sugarcane ratoon yield regardless of the use of silicate; however, they did not affect the technological quality.

\section{References}

Anderson, D. L. 1991. Soil and leaf nutrient interaction following application of calcium silicate slag to sugarcane. Fertilizer Research 30: 9-18.

Anderson, D. L., D. B. Jones, and G. H. Snyder. 1987. Response of a rice and sugar cane relation to calcium silicate slag on Everglades Histossols. Agronomy Journal 79: 531-535.

Basanta, M. V., D. Dourado-Neto, K. Reichardt, O. O. S. Bacchi, J. C. M. Oliveira, P. C. O. Trivelin, L. C. Timm, T. T. Tominaga, V. Correchel, F. A. M. Cássaro, L. F. Pires, and J. R. de Macedo. 2003. Management effects on nitrogen recovery in a sugarcane crop grown in Brazil. Geoderma 116: 235-248 (in Portuguese).

Basto, J. C. H. A. G., J. O. Cazetta, and R. M. Prado. 2010. Corrective materials and nitrogen in the nutrition and dry matter production of sugarcane cultivated in pots. Interciencia 35: 55-58 (in Portuguese).

Bataglia, O. C., A. M. C. Furlani, J. P. F. Teixeira, P. R. Furlani, and J. R. Gallo. 1983. Methods for chemical analysis of plants. Campinas, Brazil: Instituto Agronômico (in Portuguese).

Brito, A. S., P. L. Libardi, and P. J. Ghiberto. 2009. Water balance components in soils cultivated with sugarcane, with and without nitrogen fertilization. Revista Brasileira de Ciência do Solo 33: 295-303 (in Portuguese).

Cantarella, H., and P. C. O. Trivelin. 2001. Determination of total nitrogen in soil. In: Chemical Analysis for the Fertility Evaluation of Tropical Soils, eds. B. van Raij, J. C. Andrade, H. Cantarella, and J. A. Quaggio. Campinas, Brazil: Instituto Agronômico de Campinas (in Portuguese).

CONSECANA-SP. 2006. Sugarcane, Sugar and Ethanol Producers Council of São Paulo State. Instruction Manual. Piracicaba, Brazil: CONSECANA-SP (in Portuguese).

Donagemma, G. K., H. A. Ruiz, V. H. Alvarez, P. A. Ferreira, R. B. Cantarutti, A. T. Silva, and G. C. Figueiredo. 2008. Distribution of ammonium, nitrate, potassium, and phosphorus in columns of fertigated latosols. Revista Brasileira de Ciência do Solo 32: 2493-2504 (in Portuguese). 
EMBRAPA. 2006. Brazilian system of soil classification. Rio de Janeiro: Embrapa Solos.

Fonseca, I. M. 2011. Soil chemical properties, nutrition and yield of sugarcane plant due to the application of nitrogen and slag. Thesis, Sao Paulo State University, - FCAV - Campus of Jaboticabal, Jaboticabal, Brazil (in Portuguese).

Fonseca, I. M., R. M. Prado, T. A. R. Nogueira, and J. C. Barbosa. 2011. Macronutrients in marandu palisade grass as influenced by lime, slag, and nitrogen fertilization. Communications in Soil Science and Plant Analysis 42: 844-857.

Gava, G. J. C., P. C. O. Trivelin, A. C. Vitti, and E. M. W. Oliveira. 2003. Recovery of nitrogen $\left({ }^{15} \mathrm{~N}\right)$ from urea and cane trash by sugar cane ratoon (Saccharum spp.). Revista Brasileira de Ciência do Solo 27: 621-623 (in Portuguese).

Holland, E. A., and D. C. Coleman. 1987. Litter placement effects on microbial and organic matter dynamics in an agro ecosystem. Ecology 68: 425-433.

Korndörfer, G. H., H. S. Pereira, and A. Nolla. 2004. Silicon analysis: Soil, plants and fertilizer. Boletim Técnico, 2. Uberlândia, Brazil: GPSi-ICIAG-UFU.

Kraska, J. E., and G. A. Breitenbeck. 2010. Simple, robust method for quantifying silicon in plant tissue. Communications in Soil Science and Plant Analysis 41: 2075-2085.

Leite, G. M. V., L. A. B. Andrade, J. C. Garcia, and I. A. Anjos. 2008. Effects of sources and dosages of calcium silicate on yield and quality of sugarcane, cultivar SP80-1816. Ciência Agrotecnologia 32: 1120-1125 (in Portuguese).

Marschner, H. 1995. Beneficial mineral elements: Silicon. In: Mineral Nutrition Of Higher Plants. San Diego, CA: Academic Press.

Matichenkov, V. V., and D. V. Calvert. 2002. Silicon as a beneficial element for sugarcane. Journal American Society of Sugarcane Technologists 22: 21-30.

Pereira, H. S., A. J. M. Gama, M. S. Camargo, and G. S. Krondorfer. 2010. Reactivity of silicate slags of the iron and steel industry. Ciência e Agrotecnologia 34: 382-390 (in Portuguese).

Pimentel-Gomes, F. E., and C. H. Garcia. 2002. Applied statistics to agronomic and forest experiments: exposition with guidance and examples for applicative use. Piracicaba, Brazil: FEALQ (in Portuguese).

Prado, R. M., and M. A. Pancelli. 2008. Sugarcane ratoon response to nitrogen application in a no burn harvesting system. Bragantia 67: 951-959 (in Portuguese).

Primavesi, A. C., O. Primavesi, L. A. Corrêa, H. Cantarella, and A. G. Silva. 2005. Cations and anions uptake by coastcross grass fertilized with urea and ammonium nitrate. Pesquisa Agropecuária Brasileira 40: 247-253 (in Portuguese).

Ripoli, T. C. C., and M. L. C. Ripoli. 2004. Sugarcane Biomass: Harvest, Energy and Environment. Piracicaba, Brazil: Barros \& Marques Ed. Eletrônica. (in Portuguese).

Rossetto, R., A. Spironello, H. Cantarella, and J. A. Quaggio. 2004. Sugarcane response to liming and potassium fertilization. Bragantia 63: 105-119 (in Portuguese).

Shekinah, D. E., B. Sundara, and P. Rakkiyappan. 2012. Relative significance of N nutrition on yield, quality and ethanol in sugarcane (Saccharum species hybrid) plant: Ratoon system. Sugar Tech. 14: 134-137.

Spironello, A., B. van Raij, C. P. Penatti, H. Cantarella, J. L. Morelli, J. Orlando Filho, M. G. A. Landell, and R. Rossetto. 1997. Sugarcane. In: Recommendations of Fertilization and Liming for São Paulo State, eds. B. van Raij, H. Cantarella, J. A. Quaggio, and A. M. C. Furlani, pp. 237-239. Campinas, Brazil: Instituto Agronômico (in Portuguese).

Taiz, L., and E. Zeiger. 2009. Mineral nutrition. In: Plant Physiology, pp. 95-116. Deerfield, MA: Sinauer Associates.

Thornburn, P. J., R. van Antwerpen, J. H. Meyer, and C. N. Bezuidenhout. 2002. The impact of trash management on soil carbon and nitrogen: I modelling long-term experimental results in South African sugar industry. South Africa Sugar Technology Association 76: 260-268.

van Raij, . 2011. Soil Fertility and Nutrient Management. Piracicaba, Brazil: IPNI (in Portuguese).

van Raij, B., J. C. Andrade, H. Cantarella, and J. A. Quaggio. 2001. Chemical Analysis for Soil Fertility Evaluation. Instituto Agronômico (in Portuguese).

van Raij, B., and H. Cantarella. 1997. Other industrial crops. In: Recommendations of Fertilization and Liming for São Paulo State, eds. B. van Raij, B. H. Cantarella, J. A. Quaggio, and A. M. C. Furlani, pp. 233-239. Campinas, Brazil: Instituto Agronômico. 